\title{
Effect of Mastitis on Pharmacokinetics of Levofloxacin Following Single Dose Intravenous Administration in Goats
}

\author{
Mahendra Ram¹, Vishakha Singh ${ }^{1}$, Birendra Kumar Roy ${ }_{-}^{*}$, Raju Prasad ${ }^{1}$ and Kaushal Kumar Singh ${ }^{2}$
}

${ }^{1}$ Department of Pharmacology \& Toxicology, College of Veterinary Science \& A. H., Ranchi -834006, Jharkhand, India

${ }^{2}$ Department of Veterinary pathology, College of Veterinary Science \& A. H., Ranchi-834006, Jharkhand, India

\begin{abstract}
Disposition kinetics of levofloxacin was investigated after single dose intravenous administration at the dose of $10 \mathrm{mg} / \mathrm{kg}$ in six healthy and six mastitic Black Bengal lactating goats. Mastitis was induced in goats by coagulase positive Staphylococcus aureus. The maximum milk concentration was higher in mastitic goats $(17.01 \pm 0.67 \mu \mathrm{g} /$ $\mathrm{ml})$ as compared to healthy $(14.75 \pm 0.95 \mu \mathrm{g} / \mathrm{ml})$. The therapeutic milk concentration in mastitic goats $(0.10 \pm 0.00$ to $16.61 \pm 0.70 \mu \mathrm{g} / \mathrm{ml}$ ) was maintained for $48 \mathrm{~h}$, which was significantly longer than healthy goats $(36 \mathrm{~h})$. The $\mathrm{t}_{1 / 2} \beta$ in plasma $(5.08 \pm 0.18 \mathrm{~h})$ and milk $(7.28 \pm 0.09 \mathrm{~h})$ of mastitic goats were significantly longer than healthy goats $(4.04 \pm 0.24$ and $4.16 \pm 0.76 \mathrm{~h})$. The total body clearence in plasma of healthy goats $(5.64 \pm 0.78 \mathrm{ml} / \mathrm{kg} / \mathrm{min}) \mathrm{was}$ almost similar to mastitic goats $(5.82 \pm 0.44 \mathrm{ml} / \mathrm{kg} / \mathrm{min})$. The $\mathrm{AUC}_{\text {milk }} / \mathrm{AUC}_{\text {plasma }}$ ratio (3.36) in mastitic goats indicated extensive penetration of levofloxacin from plasma to milk. The $t_{1 / 2}$ milk $/ t_{1 / 2}$ plasma ratio was 1.43 . The AUC/MIC ratio in plasma and milk of mastitic goats were 296 and 1014 respectively. Based on the plasma kinetic parameters, it was concluded that levofloxacin may be used for treatment of mastitis in goats.
\end{abstract}

Keywords: Goats; Levofloxacin; Mastitis; Pharmacokinetics

\section{Introduction}

Levofloxacin (LVX), a third-generation fluoroquinolone and L-isomer of ofloxacin possess a broad-spectrum antimicrobial activity and active against most gram-positive, gram-negative and anaerobic bacteria [1-2]. It is also active against several species of Staphylococci, Streptococci including Stretococcus pneumonia, Bacteroides, Clostridium, Haemophilus, Moraxella, Legionella, Mycoplasma and Clamydia [3,4]. It acts by selective inhibition of bacterial enzymes DNA gyrase and Topoisomerase IV [5]. LVX is widely distributed throughout the body and penetrates well into most body fluids and its uptake by phagocytic cells makes it suitable for use against intracellular pathogens [3]. Levofloxacin concentrations in tissues and fluids are generally greater than those observed in plasma, but penetration into the cerebrospinal fluid is relatively poor [6]. LVX is excreted through urine as unchanged drug and less than $5 \%$ is metabolized in the liver to demethyl-levofloxacin and levofloxacin- $\mathrm{N}$-oxide [7] and excreted in the urine of rats and humans [4]. Fluoroquinolones act by a concentrationdependent killing mechanism, whereby the optimal effect is attained by the administration of high doses over a short period of time [8].

Mastitis is an inflammatory condition of the mammary gland irrespective of causes and is a global problem in livestock [9]. It is characterized by physical, chemical and microbiological changes in milk and pathological changes in glandular tissues of mammary gland. The most frequent isolate of bacteria causing caprine mastitis is Staphylococcus spp [10-12].

It has also been evidenced that mastitis has an effect on the milk concentrations of antimicrobials in goats [9]. However, there is paucity of information on the pharmacokinetics of LVX and its diffusion into milk especially in mastitic goats. Most of the published papers about mastitis treatments report recommendations adapted from results obtained in cows. Inappropriate low doses of an antibiotic can lead to ineffective therapeutic blood or milk concentrations. In view of the marked variation in the kinetic variables of antimicrobials in diseased animals [13], the present study was undertaken to determine the pharmacokinetic study and milk penetration of LVX following single intravenous (i.v.) administration in healthy and lactating mastitic goats for its clinical application.

\section{Materials and Methods}

Twelve clinically healthy Black Bengal lactating goats (14-20 kg) of 2 to 2.5 years were used in this study. Levofloxacin (Loxof) infusion was injected i.v. @ $10 \mathrm{mg} / \mathrm{kg}$ body weight to each of six healthy and six mastitic goats. The blood samples were collected in heparinized test tubes from left jugular vein by venipuncture and milk samples were collected manually from both the quarters in sterile test tubes by hand milking at $0,2.5,5,10,15,20,30,45 \mathrm{~min}$ and 1, 2, 3, 4, 6, 8, 12, 24, 36, 48 and $60 \mathrm{~h}$ following drug administration.

Mastitis was induced in each of six goats by coagulase positive Staphyloccous aureus by the method of Sar et al. [9] with slight modification. After six hours of induction, animals showed the symptoms of inflammation, fever $\left(103^{\circ} \mathrm{F}\right.$ to $104^{\circ} \mathrm{F}$, persisted for 6 hours) and inappetance. The goats also showed partial agalactia and defecated semisolid faeces. Mastitis in goats was confirmed by standard tests (California mastitis test, Bromocresol Purple test, Somatic Cell Count, Catalse Test).

Quantitative estimation of LVX in plasma and milk were done by HPLC [14] with UV-VIS detector. The sensitivity of the method was $0.065 \mu \mathrm{g} / \mathrm{ml}$ and linearity was 0.999 in plasma and milk both. The mean percentage of inter- and intra-day coefficient of variation was $7.5 \%$ and $4.13 \%$ in plasma and $9.1 \%$ and $4.9 \%$ in milk respectively. The percentage

${ }^{*}$ Corresponding author: Dr. B. K. Roy, Department of Pharmacology \& Toxicology, College of Veterinary Science \& A. H., Ranchi-834006, Jharkhand, India, Tel. +91651-2450759; Fax: +91 -651-2450759, E-mail: roybk2001@yahoo.co.in

Received May 20, 2011; Accepted June 13, 2011; Published June 21, 2011

Citation: Ram M, Singh V, Roy BK, Prasad R, Singh KK (2011) Nicotinamide Phosphoribosyltransferase in Rheumatoid Arthritis. J Bioanal Biomed 3: 081-084. doi:10.4172/1948-593X.1000048

Copyright: (c) 2011 Ram M, et al. This is an open-access article distributed under the terms of the Creative Commons Attribution License, which permits unrestricted use, distribution, and reproduction in any medium, provided the original author and source are credited. 
Citation: Ram M, Singh V, Roy BK, Prasad R, Singh KK (2011) Nicotinamide Phosphoribosyltransferase in Rheumatoid Arthritis. J Bioanal Biomed 3: 081-084. doi:10.4172/1948-593X.1000048

of recovery of LVX from plasma and milk were $95.33 \%$ and $93.47 \%$ respectively.

The plasma protein binding of LVX was determined by the "equilibrium dialysis" technique [15,16]. Plasma standard solutions of LVX of $6.25,12.5,25$ and $50 \mu \mathrm{g} / \mathrm{ml}$ were prepared. The concentrations of drug in plasma and buffer were read with the help of HPLC and plasma protein binding of drug was calculated by the formula given by Linkenheinmer et al. [17].

Plasma protein binding $=\frac{\text { Conc. of drug in plasma }- \text { Conc. of drug in buffer }}{\text { Conc. of drug in plasma }} \times 100 \%$

\section{Statistical Analysis}

Variability among the pharmacokinetic data of levofloxacin due to induced mastitis was assessed by t-test according to the method of Snedecor and Cochran [18].

\section{Results}

The semilogerithmic plot of comparative mean plasma and milk concentrations of LVX in healthy and mastitic goats are depicted in Figure 1 and 2 respectively. The therapeutic plasma concentration $\left(\mathrm{Cp}_{\text {ther }}\right)$ of LVX in healthy and mastitic goats was maintained for $24 \mathrm{~h}$ in mastitic as well as healthy goats. The maximum milk concentrations $\left(\mathrm{Cm}_{\max }\right)$ of LVX in healthy and mastitic goats were $14.75 \pm 0.95$ and

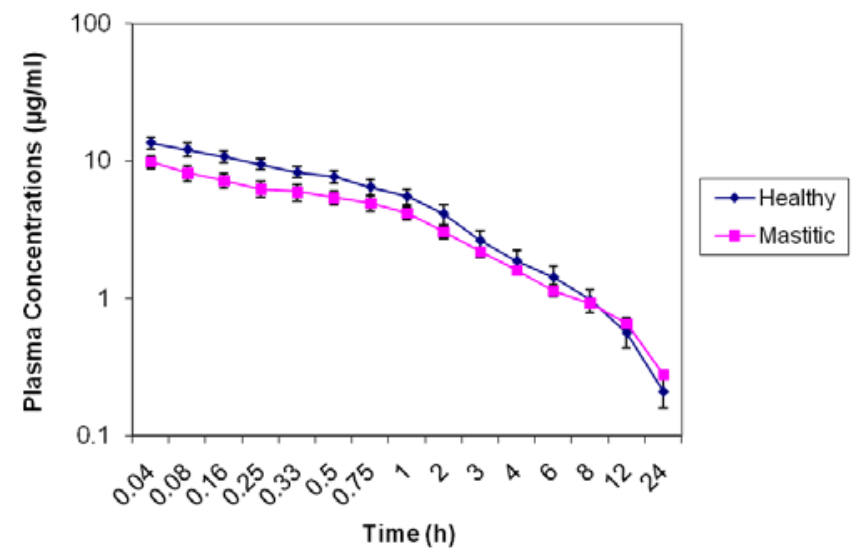

Figure 1: Semilogarithmic plot of comparative plasma concentrations $(\mu \mathrm{g} / \mathrm{ml})$ (Mean $\pm S E$ ) of LVX in healthy and mastitic goats $(n=6)$ after single i.v. dose $(10$ $\mathrm{mg} / \mathrm{kg}$ ) administration.

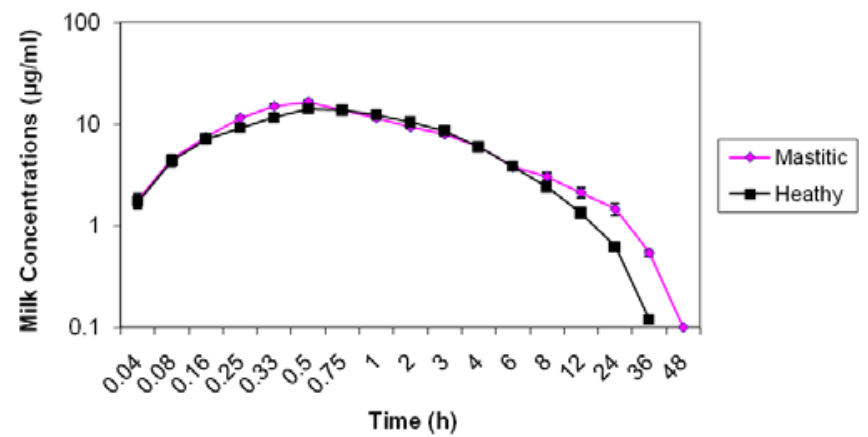

Figure 2: Semilogarithmic plot of comparative milk concentrations $(\mu \mathrm{g} / \mathrm{ml})$ (Mean \pm SE) of LVX in healthy and mastitic goats $(n=6)$ after single i.v. dose $(10 \mathrm{mg} /$ $\mathrm{kg}$ ) administration.

\begin{tabular}{|l|l|l|l|}
\hline Kinetic parameters & Healthy & Mastitic & P value \\
\hline $\mathrm{C}^{\circ} \mathrm{p}(\mu \mathrm{g} / \mathrm{ml})$ & $15.51 \pm 1.41$ & $12.48 \pm 1.36$ & $0.11^{\mathrm{NS}}$ \\
\hline $\mathrm{t}_{1 / 2} \beta(\mathrm{h})$ & $4.04 \pm 0.24$ & $5.08 \pm 0.18$ & $0.01^{*}$ \\
\hline $\mathrm{Vd}_{\text {area }}(\mathrm{L} / \mathrm{kg})$ & $1.89 \pm 0.18$ & $2.56 \pm 0.21$ & $0.05^{\mathrm{NS}}$ \\
\hline $\mathrm{AUC}(\mathrm{mg} / \mathrm{L} . \mathrm{h})$ & $33.68 \pm 5.11$ & $29.62 \pm 2.18$ & $0.52^{\mathrm{NS}}$ \\
\hline $\mathrm{MRT}(\mathrm{h})$ & $5.61 \pm 0.49$ & $7.77 \pm 0.28$ & $0.01^{* *}$ \\
\hline $\mathrm{Cl}_{\mathrm{B}}(\mathrm{ml} / \mathrm{kg} / \mathrm{min})$ & $5.64 \pm 0.78$ & $5.82 \pm 0.44$ & $0.86^{\mathrm{NS}}$ \\
\hline $\mathrm{K}_{12}\left(\mathrm{~h}^{-1}\right)$ & $2.44 \pm 0.70$ & $6.24 \pm 1.35$ & $0.05^{*}$ \\
\hline $\mathrm{K}_{21}\left(\mathrm{~h}^{-1}\right)$ & $2.83 \pm 0.97$ & $3.59 \pm 0.59$ & $0.55^{\mathrm{NS}}$ \\
\hline $\mathrm{K}_{2}\left(\mathrm{~h}^{-1}\right)$ & $0.37 \pm 0.05$ & $0.39 \pm 0.04$ & $0.76^{\mathrm{NS}}$ \\
\hline $\mathrm{T} / \mathrm{P}$ ratio & $1.05 \pm 0.17$ & $1.77 \pm 0.28$ & $0.07^{\mathrm{NS}}$ \\
\hline
\end{tabular}

NS = Non significant; ${ }^{*} P<0.05 ;{ }^{*} P<0.01$.

$C^{\circ} p(\mu \mathrm{g} / \mathrm{ml})=$ Zer-time plasma concentration; $t_{1 / 2} \alpha(h)=$ Distribution plasma halflife; $t_{1 / 2} \beta(h)=$ Elimination plasma half-life; $\quad V_{\text {area }}=$ Volume of distribution based on area under curve; $A \cup C=$ Area under curve; $\mathrm{Cl}_{\mathrm{B}}=$ Total body clearance rate; $\mathrm{K}_{12}=$ Rate constant for transfer of drug from central to peripheral compartment $\mathrm{K}_{21}$ $=$ Rate constant for transfer of drug from peripheral to central compartment $\mathrm{K}_{2=}$ elimination from central compartment. MRT = Mean residence time; T/P ratio $\stackrel{2=}{=}$ Tissue to plasma ratio.

Table 1: Kinetic profile (Mean \pm SE) of LVX (10 mg/kg, i.v.) in Plasma of healthy and mastitic goats.

\begin{tabular}{|l|l|l|l|}
\hline Kinetic parameters & Healthy & Mastitic & P value \\
\hline $\mathrm{Cm}_{\max }(\mu \mathrm{g} / \mathrm{ml})$ & $14.75 \pm 0.95$ & $17.01 \pm 0.67$ & $0.11^{\mathrm{NS}}$ \\
\hline $\mathrm{t}_{1 / 2} \beta(\mathrm{h})$ & $4.61 \pm 0.76$ & $7.28 \pm 0.09$ & $0.00^{* *}$ \\
\hline $\mathrm{Vd}_{\text {area }}(\mathrm{L} / \mathrm{kg})$ & $0.95 \pm 0.05$ & $1.05 \pm 0.05$ & $0.23^{\mathrm{NS}}$ \\
\hline $\mathrm{AUC}(\mathrm{mg} / \mathrm{L} . \mathrm{h})$ & $82.18 \pm 2.78$ & $101.49 \pm 6.23$ & $0.03^{*}$ \\
\hline $\mathrm{MRT}$ & $7.10 \pm 0.20$ & $10.63 \pm 0.30$ & $0.00^{* *}$ \\
\hline $\mathrm{Cl}_{\mathrm{B}}(\mathrm{ml} / \mathrm{kg} / \mathrm{min})$ & $2.04 \pm 0.07$ & $1.67 \pm 0.09$ & $0.01^{*}$ \\
\hline $\mathrm{T}_{\max }(\mathrm{h})$ & $0.58 \pm 0.05$ & $0.47 \pm 0.03$ & $0.09^{\mathrm{NS}}$ \\
\hline
\end{tabular}

NS = Non significant; ${ }^{*} \mathrm{P}<0.05 ;{ }^{*} \mathrm{P}<0.01$.

$\mathrm{Cm}_{\max }=$ maximumr milk concentration; $\mathrm{t}_{1 / 2} \beta \mathrm{M}=$ elimination half-life in milk; $\mathrm{Vd}_{\text {rea }}$ $=$ volume of distribution based on area under curve in milk; $A U C=$ area under the curve; $\mathrm{MRT}=$ Mean residence time; $\mathrm{Cl}_{\mathrm{BM}}$, =total clearance in milk and $\mathrm{T}_{\operatorname{maxM}}=$ time to peak concentration in milk

Table 2: Kinetic profile (Mean \pm SE) of LVX $(10 \mathrm{mg} / \mathrm{kg}$, i.v.) in milk of healthy and mastitic goats.

$17.01 \pm 0.67 \mu \mathrm{g} / \mathrm{ml}$ respectively and was attained in $0.58 \pm 0.05 \mathrm{~h}$, and $0.47 \pm 0.03 \mathrm{~h}$ respectively. The therapeutic milk concentration $\left(\mathrm{Cm}_{\text {ther }}\right)$ was maintained for $48 \mathrm{~h}$ in mastitic and $36 \mathrm{~h}$ in healthy goats. The mean $( \pm$ SE) values of plasma and milk pharmacokinetic parameters of levofloxacin after single dose i.v. administration in healthy and mastitic goats are shown in Table 1 and 2. The zero-time plasma concentration $\left(\mathrm{C}^{\circ} \mathrm{p}\right)$ in healthy and mastitic goats were $15.51 \pm 1.41 \mu \mathrm{g} / \mathrm{ml}$ and 12.48 $\pm 1.36 \mu \mathrm{g} / \mathrm{ml}$ respectively. The elimination half-life $\left(\mathrm{t}_{1 / 2 \mathrm{\beta}}\right)$ in mastitic goats $(5.08 \pm 0.18 \mathrm{~h})$ was significantly $(\mathrm{p}<0.05)$ higher to that in healthy goats $(4.04 \pm 0.24 \mathrm{~h})$. The total body clearance $\left(\mathrm{Cl}_{\mathrm{B}}\right)$ in mastitic and healthy goats were $5.82 \pm 0.44 \mathrm{ml} / \mathrm{kg} / \mathrm{min}$ and $5.64 \pm 0.78 \mathrm{ml} / \mathrm{kg} / \mathrm{min}$ respectively. Apparent volume of distribution $\left(\mathrm{Vd}_{\text {area }}\right)$ in mastitic and healthy goats were $2.56 \pm 0.21 \mathrm{~L} / \mathrm{kg}$ and $1.89 \pm 0.18 \mathrm{~L} / \mathrm{kg}$ respectively. The rate of transfer of drug from central to peripheral compartment $\left(\mathrm{K}_{12}\right)$ in mastitic goats $\left(6.24 \pm 1.35 \mathrm{~h}^{-1}\right)$ was significantly $(\mathrm{p}<0.05)$ higher than healthy $\left(2.44 \pm 0.70 \mathrm{~h}^{-1}\right)$. The plasma protein binding of levofloxacin was found to be $27.46 \pm 4.48 \%$.

The milk half-life $\left(\mathrm{t}_{1 / 2 \beta \mathrm{M}}\right)$ in mastitic goats $(7.28 \pm 0.09 \mathrm{~h})$ was significantly $(\mathrm{p}<0.01)$ higher than healthy $(4.61 \pm 0.76 \mathrm{~h})$. The total body clearance in milk $\left(\mathrm{Cl}_{\mathrm{BM}}\right)$ of mastitic goats $(1.67 \pm 0.09 \mathrm{ml} / \mathrm{kg} / \mathrm{min})$ was significantly $(\mathrm{p}<0.05)$ lower than healthy goats $(2.04 \pm 0.07 \mathrm{ml} / \mathrm{kg} /$ min). The AUC/MIC ratio of milk in healthy and mastitic goats were 296 and 1014 respectively. 


\section{Discussion}

The semilogarithmic plot of plasma-level time profile of LVX after single dose i.v. administration in healthy and mastitic goats evidenced two compartment open model in all animals.

Disease conditions may influence the pharmacokinetics and pharmacodynamics of various antibiotics, including aminoglycosides and cephalosporins [19]. Fluoroquinolones are concentrationdependent antibacterials [8] and they must reach minimal inhibitory concentration $(\leq 0.1 \mu \mathrm{g} / \mathrm{ml})$ in order to be effective. The $\mathrm{Cm}_{\max }$ in case of mastitic goats $(17.01 \pm 0.67 \mu \mathrm{g} / \mathrm{ml})$ was slightly higher than healthy goats $(14.75 \pm 0.95 \mu \mathrm{g} / \mathrm{ml})$. The value was greater than those reported for pefloxacin in lactating goats [20] and danofloxacin in ewes [21].

Weak organic acids having high pKa value tend to diffuse more rapidly into the milk than acids with low pKa values [22]. It is obvious from the above findings that in the present experiment, LVX $\left(\mathrm{pKa}_{1}-6.8\right.$ and $\mathrm{pKa}_{2}-8.2$ ) diffused passively from blood ( $\left.\mathrm{pH} 7.4\right)$ to milk ( $\mathrm{pH} 8.6$ ) in mastitic goats and could cross the plasma-milk barrier at an increased rate. The concentrations of LVX in milk of mastitic goats were higher as compared to milk of healthy goats, which may be due to increased permeability and intercellular spaces of mammary epithelial cells due to the release of several chemical mediators during inflammation [23] along with damage of mammary epithelium and break down of bloodmilk barrier [24]. This finding is strengthen by a study on disposition kinetics of orbifloxacin in clinically normal lactating goats after i.v., s.c. and i.m. administration showed that orbifloxacin penetrated from blood into the milk and attained high concentrations in milk as compared to blood [25].

It has been reported that fluoroquinolones are taken up by phagocytes that carry drug at the site of infection and also engulf the infective organisms [26-29]. The cellular uptake and accumulation of levofloxacin is of major importance from therapeutic point of view against intracellular pathogens [3], especially in this case, where acute mastitis is caused by $S$. aureus. This helps in attainment of a sufficient concentration of active drug at the site of infection i.e. mammary gland and plays a crucial role in the killing of the pathogen.

The $t_{1 / \beta}$ of LVX in plasma was significantly $(p<0.01)$ longer in case of mastitic goats $(5.08 \pm 0.18 \mathrm{~h})$ as compared to healthy (4.04 \pm 0.24 h). The elimination half-life of LVX was observed to be longer in CSF ( 3.8 to $5.6 \mathrm{~h}$ ) of subjects suffering with pneumococcal meningitis as compared to blood (2.7 to $3.2 \mathrm{~h}$ ) [30]. The $\mathrm{K}_{12} / \mathrm{K}_{21}$ ratio of LVX obtained in this study was 0.93 in healthy goats while 1.69 in mastitic goats that indicated a faster drug transfer from central to peripheral compartment than from peripheral to central compartment. The T/P ratio in mastitic goats $(1.77 \pm 0.28)$ was found to be higher as compared to healthy goats $(1.05 \pm 0.17)$. The in-vitro plasma protein binding of LVX calculated in the present experiment ranged between $22.99 \pm 0.82 \%$ to $34.79 \pm 1.07$ $\%$. It is in agreement with the value of 24 to $38 \%$ [6].

The $t_{1 / 2 \beta}$ of milk $\left(t_{1 / \beta M M}\right)$ was significantly $(p<0.01)$ longer in case of mastitic goats $(7.28 \pm 0.09 \mathrm{~h})$ as compared to healthy $(4.61 \pm 0.76 \mathrm{~h})$. This indicates greater persistence of the drug at the site of inflammation and is in consonance with a report of Wise et al. [31] where gatifloxacin showed a mean plasma elimination half-life of $6.8 \mathrm{~h}$ and that in inflammatory fluid, $7.2 \mathrm{~h}$.

The $t_{1 / 2 \text { milk }} / t_{1 / 2 \text { plasma }}$ ratio (1.43) in this experiment also indicated persistence of drug in mastitic milk for longer period than in plasma. In contrast to this, ibafloxacin penetrated poorly from blood into the milk after i.v. administration in goats and was detectable in milk only till $6 \mathrm{~h}$ and persisted for shorter time in milk than in plasma $\left(\mathrm{t}_{1 / 2 \mathrm{milk}} / \mathrm{t}_{1 / 2 \mathrm{plasma}}<1\right)$ [32]. For effective systemic treatment of mastitis, drug should penetrate extensively from the blood into the milk.

The AUC in mastitic goat plasma $(29.62 \pm 2.18 \mathrm{mg} / \mathrm{l} . \mathrm{h})$ and milk $(101.49 \pm 6.23 \mathrm{mg} / \mathrm{l} . \mathrm{h})$ in the present study was higher than the AUC (7.66 mg/l.h) of LVX in calves [33], reflected coverage of a vast body area by the drug.

Fluoroquinolones possess low MIC values against many gramnegative and gram-positive microorganisms [34]. In a study of LVX in cross bred calves after i.m. administration the $\mathrm{MIC}_{90}$ of $\mathrm{LVX}$ was considered to be $0.1 \mu \mathrm{g} / \mathrm{ml}$, to cover most of the susceptible microorganisms [33]. So, here we considered the same value.

AUC/MIC and $\mathrm{Cp}_{\max } / \mathrm{MIC}$ can be used to predict the efficacy of different agents against different pathogens and to define pharmacodynamics break point [35]. In this experiment, it was found that the $\mathrm{AUC}_{\text {milk }} / \mathrm{AUC}_{\text {plasma }}$ ratio in mastitic goats was 3.43. The AUC/ MIC ratio of LVX in plasma and milk of mastitic goats were 296 and 1014 respectively, which indicates that LVX was effective against $S$. aureus as well as shows less chances of emergence of resistance. In addition the milk kinetics also point out its better clinical utility in the treatment of mastitis in goats.

On the basis of the results obtained in this study, it was concluded that levofloxacin may be effectively used in the treatment of mastitis in goats caused by $S$. aureus.

\section{Acknowledgements}

Authors acknowledge the financial help provided by Dr. N. N. Singh, Vicechancellor, Birsa Agricultural University, Ranchi, Jharkhand, India for conducting this experiment.

\section{References}

1. Davis R, Bryson HM (1994) Levofloxacin: A review of its antibacterial activity, pharmacokinetics and therapeutic efficacy. Drugs 47: 677-700.

2. North DS, Fish DN, Redington JJ (1998) Levofloxacin a second generation fluoroquinolone. Pharmacotherapy 18: 915-935.

3. Goudah A, Abo-El-Sooud K (2008) Pharmacokinetics, urinary excretion and milk penetration of levofloxacin in lactating goats. J Vet Pharmacol Ther 32 101-104.

4. Langtry HD, Lamb HM (1998) Levofloxacin. Its use in infections of the respiratory tract, skin, soft tissues and urinary tract. Drugs 56: 487-515.

5. Perry CM, Barman Balfour JA, Lamb HM (1999) Gatifloxacin. Drugs 58: 683696.

6. Fish DN, Chow AT (1997) The clinical pharmacokinetics of levofloxacin. Clin Pharmacokinet 32: 101-119.

7. Hurst M, Lamb HM, Scott LJ, Figgitt DP (2002) Levofloxacin. An updated review of its use in the treatment of bacterial infections. Drugs 62: 2127-2167.

8. Drusano GL, Johnson DE, Rosen M, Standiford HC (1993) Pharmacodynamics of a fluoroquinolone antimicrobial agent in a neutropenic rat model of Pseudomonas sepsis. Antimicrob Agents Chemother 37: 483-490.

9. Sar TK, Mandal TK, Das SK, Chakraborty AK, Bhattacharyya A (2006) Pharmacokinetics of ceftriaxone in healthy and mastitic goats with special reference to its interaction with Polyherbal drug (Fibrosin). International Journal of Applied Research Veterinary Medicine 4: 142-154

10. Taponen S, Jantunen A, Pyorala E, Pyorala S (2003) Efficacy of targeted 5-day combined parentral and intramammary treatment of clinical mastitis caused by penicillin-resistant Staphylococcus aureus. Acta Veterinaria Scandinavica 44 53-62.

11. Barkema HW, Schukken YH, Zadoks RN (2006) Invited Review: The role of cow, pathogen and treatment regimen in the therapeutic success of bovine Staphylococcus aureus mastitis. J Dairy Sci 89: 1877-1895.

12. Bradley AJ, Green MJ (2009) Factors affecting cure when treating bovine 
Citation: Ram M, Singh V, Roy BK, Prasad R, Singh KK (2011) Nicotinamide Phosphoribosyltransferase in Rheumatoid Arthritis. J Bioanal Biomed 3: 081-084. doi:10.4172/1948-593X.1000048

clinical mastitis with cephalosporin based intramammary preparations. J Dairy Sci 92: 1941-1953.

13. Kumar S, Roy BK, Kumar V, Singh V (2009) Pharmacokinetics of Levofloxacin after IV bolus in healthy and febrile calves. Online Journal of Pharmacology and Pharmacokinetics 5: 54-64.

14. Santoro MI, Kassab NM, Singh AK, Kedor-Hackman RM (2006) Quantitative determination of gatifloxacin, levofloxacin, lomefloxacinand pefloxacin fluoroquinolonic antibiotics in pharmaceutical preparations by high-performance liquid chromatography. J Pharm Biomed Anal 40: 179-184.

15. Davis BD (1943) The binding of sulfonamide drugs to plasma proteins. A factor in determining the distribution of drug in the body. J Clin Invest 2: 753-762.

16. Sisodia CS, Millen GE, Stowe CM (1965) Protein binding of sulfonamides and quinine in bovine milk and plasma. Indian Vet J 42: 7-16.

17. Linkenheinmer WH, Stolzenberg SJ, Wozniac LA (1965) The pharmacology of sulfaethoxypyridazine in the heifer. J Pharmacol Exp Ther 149: 280-287.

18. Snedecor CW, Cochran WG (1994) Statistical methods. $7^{\text {th }}$ edition. Oxford and IBH Publishing co New Delhi.

19. Bergeron MG, Bergeron $Y$ (1986) Influence of endotoxin on the intra-renal distribution of gentamicin, natilmicin, tobramycin and cephaloyhin. Antimicrobial agents and Chemotherapy 29: 7-12

20. Abd El- Aty AM, Goudah A (2002) Some pharmacokinetic parameters of pefloxacin in lactating goats. Vet Res Commun 26: 553-561.

21. Shem-Tov M, Ziv G, Glickman A, Saran A (1997) Pharmacokinetics and penetration of danofloxac in from the blood into the milk of ewes. Vet Res 28: 571-579.

22. Miller GE, Stowe CM (1967) Influence of oxytocin on diffusion of sulfonamides from plasma into bovine milk. J Dairy Sci 50: 840-846.

23. Post LO, Farrell DE, Cope CV, Baker JD, Myers MJ (2002) The effect of endotoxin and dexamethason on enrofloxacin pharmacokinetic parameters in swine. J Pharmacol Exp Ther 889-895.

24. Zhao X, Lacasse $P$ (2007) Mammary tissue damage: Dairy bovine mastitis. Cause and control. J Anim Sci 86: 57-65.
25. Marín P, Escudero E, Fernández-Varón E, Cárceles CM (2007) Pharmacokinetics and milk penetration of orbifloxacin after intravenous, intramuscular and subcutaneous administration in lactating goats. J Dairy Sci 90: 4219-4225.

26. Carlier MB, Scorneaux B, Zenebergh A, Desnottes JF, Tulkens PM (1990) Cellular uptake, localization and activity of fluoroquinolones in uninfected and infected macrophages. J Antimicrob Chemother 26: 27-39.

27. Yamamoto T, Kusajima H, Hosaka M, Fukuda H, Oomari Y, et al. (1996) Uptake and intracellular activity of AM-11155 in phagocytic cells. Antimicrob Agents Chemother 40: 2756-2759.

28. Loo KC, Cario AC, Zhang F, Walters JD (1997) Regulation of ciprofloxacin uptake in human promyelocytic leukemia cells and polymorphonuclear leucocytes. J Leukoc Biol 61: 619-623.

29. Memin E, Panteix G, Revol A (1997) Carrier-mediated system for pefloxacin uptake in human monocytes. J Antimicrob Chemother 40: 263-268.

30. Lutsar I, Friedland IR, Wubbel L, McCoig CC, Jafri HS, et al. (1998) Pharmacodynamics of gatifloxacin in cerebrospinal fluid in experimental cephalosporin-resistant pneumococcal meningitis. Antimicrob Agents Chemother 42: 2650-2655.

31. Wise R, Andrews JM, Ashby JP, Marshall J (1999) A study to determine pharmacokinetics and inflammatory fluid penetration of Gatifloxacin following single oral dose. J Antimicrob Chemother 44: 701-704.

32. Marín P, Escudero E, Fernández-Varón E, Cárceles CM (2007) Pharmacokinetics and milk penetration of Ibafloxacin after intravenous administration in Lactating Goats. Can J Vet Res 71: 74-76.

33. Dumka VK, Srivastava AK (2006) Pharmacokinetics, urinary excretion and dosage regimen of levofloxacin following a single intramuscular administration in cross bred calves. J Vet Sci 7: 333-337.

34. Prescott JF, Baggot JD (1993) Antimicrobial therapy in Veterinary Medicine. $2^{\text {nd }}$ edition lowa State University Press, Ames USA.

35. Turnidge $\mathrm{J}$ (1999) Pharmacokinetics and pharmacodynamics of fluoroquinolones. Drugs 58: 29-36. 